\title{
Study on the Production effect and Prevention Index of the Forthputting of Sonsau Cocuus Sinensis Chen on the Pinus Tabulaeformis
}

\author{
Guozan Fu ${ }^{1}$, Hansi Fu ${ }^{1}$, Qingrui Zhang ${ }^{1}$, Xinglong Peng ${ }^{2}$ \\ ${ }^{1}$ Henan Forestry Vocational College, Luoyang, Henan 471002, China; ${ }^{2}$.Sanmenxia Forestry Bureau of Henan Province, \\ Sanmenxia, Henan 472000
}

\begin{abstract}
The growth of Pinus tabulaeformis is influenced by the sonsau cocuus sinensis chen. When the insect density is more than 300-350 head/hundred beam conifer, sonsau cocuus sinensis chen occurred significantly influence the Pinus tabulaeformis's growth. When the insect density reached 250-300 head/100 beam coniferous, sonsau cocuus sinensis chen significantly influence the accumulation of Pinus tabulaeformis volume. To determine the sonsau cocuus sinensis chen 2nd instar nymph theory control index was 220.5 /hundred beam needles has a guiding significance to the production practice.
\end{abstract}

Keywords-sonsau cocuus sinensis chen; pinus tabulaeformis ; control index.

Sonsau cocuus sinensis Chen also known as the pine needle scale, takes place every year in Henan area of a generation, late June to mid August for diapause period, from August to September and the following March to April for the harmful period, mainly in the 2nd instar nymphs of harm, harmful mainly to oil Pinus tabulaeformis. Harmfull Methods: Parasitism in the pine needles' inside in the current year, by mouthsucking the juice of the leaves, resulting in coniferous become yellow and fall,thus can't grow new leaves, eventually leading to branches to wilt, seriously affected the growth of pine. In recent years, sonsau cocuus sinensis chen pest on Pinus tabulaeformis showed an upward trend year by year. By the continuous observation and investigation on the test land, and study of the change of the amount of the sonsau cocuus sinensis chen in different population of density level, and based on the analysis to determine the 2nd instar nymph period of damage control index, so as to provide a scientific basis for prediction and prevention and cure of the sonsau cocuus sinensis chen

\section{B. Sampling method}

Pine crown is divided into upper, middle and lower 3 layers and the South and North 2 range, a total of 6 parts, selected 2 branches from each part to count their Insect population (each branch is not less than 20 beam), the average of every branch of insect pest density is the density of Pinus tabulaeformis. Per 100 beam leaves of 50 head of grade 1, divided into 9 insect density level.

2) Measurement of diameter growth

From the beginning of 2004, March of each year (two instar), investigate the number of insect population on each Pinus tabulaeformis, and mark it according to the

\section{MATERIALS AND METHODS}

\section{A. General situation of the observation land}

Observatory land is located in the East Bay of Lushi County of Sanmenxia city in Henan. It is a warm and semi-arid continental monsoon climate, the annual average temperature is 12.6 centidegree, the coldest Month is January, the hottest Month is July and frost free period is $184 \mathrm{D}$; an average annual sunshine hours are $2118 \mathrm{~h}$; the average annual rainfall is $647.8 \mathrm{~mm}$, mainly occurred in July September[1].And this forest tree's characteristics are mainly for Pinus tabulaeformis, followed by Carya cathayensis, Robinia pseudoacacia etc 、 under the bush shrubs Ziziphus jujubavar.spinosa、

Vitex negundo、Pyrus calleryana ect.Vitex negundo, ground cover plants are Themeda triandra and the Pennisetum flaccidum etc.

This experiment include 4 standard representative sites, conditions as the following Tab.1,each standard area of $50 \mathrm{mx} 50 \mathrm{~m}$, at the same time requirements for the number of Pinus tabulaeformis of each standard site is not in less than 90 plants.

TABLE.I. THE STANDARD SITE CONDITION

\begin{tabular}{ccccccc}
\hline $\begin{array}{c}\text { Standar } \\
\text { d No. }\end{array}$ & $\begin{array}{c}\text { The } \\
\text { Height }(\mathrm{m} \\
\text { ) }\end{array}$ & $\begin{array}{c}\text { The } \\
\text { Aspect }\end{array}$ & $\begin{array}{c}\text { The } \\
\text { slop } \\
\mathrm{e}\end{array}$ & $\begin{array}{c}\text { The } \\
\text { percentage } \\
\text { of infection } \\
\text { of the insect } \\
\text { pest of plant } \\
(\%)\end{array}$ & $\begin{array}{c}\text { Crown } \\
\text { Density }\end{array}$ & $\begin{array}{c}\text { The } \\
\text { average } \\
\text { age of } \\
\text { the } \\
\text { plant (a) }\end{array}$ \\
\hline 1 & 820 & $\begin{array}{c}\text { The } \\
\text { Piedmont } \\
\text { Plain } \\
\text { The } \\
\text { Valley } \\
\text { Flat }\end{array}$ & 0 & 79 & 0.8 & 40 \\
3 & 1040 & 0 & 90 & 0.7 & 50 \\
4 & 1150 & $\begin{array}{c}\text { Slope } \\
\text { The } \\
\text { sunny }\end{array}$ & 9 & 86 & 0.8 & 40 \\
\hline & 11.5 & 88 & 0.8 & 40 \\
\hline
\end{tabular}

1) Definition of the insect mouth density level:

insect density level. At the same time measure the diameter of each Pinus tabulaeformis and mark it. Record every survey data. At the same time of the following year, by five point sampling method, which is near the four corners of the stardard site, namely around the center point randomly selected not less than 2 plants of Pinus tabulaeformis according to the insect population density level, a total of 120 samples .Measuring and recording the strain, calculated the amount of annual growth of diameter at breast height. To the year 2008, records 4 times, made 4 sets of data. 
3) Calculation of volume growth

According to volume formula in the ",the main species of tree volume and shape high table, Henan Province ",which is issued in july,1998, calculate 4 annual growth volume under the influence of the insect population density.

The mountain tree Unitary standing tree volume calculation formula is as follows:

$$
\mathrm{V}=\mathrm{a}(\mathrm{b}+\mathrm{cD}) \mathrm{e} \cdot[\mathrm{f}+\mathrm{g}(\mathrm{b}+\mathrm{cD})-\mathrm{h}(\mathrm{b}+\mathrm{cD}) 2] \mathrm{i} \text {. }
$$

D diameter

For Pinus tabulaeformis, type in: $\mathrm{a}=0.000093059 \quad \mathrm{~b}=-0.3153 \quad \mathrm{c}=0.98317 \quad \mathrm{e}=1.992682$

\section{$\mathrm{f}=0.45060 \quad \mathrm{~g}=0.621517 \quad \mathrm{~h}=0.0051748 \quad \mathrm{i}=0.6711661$}

4) Determination of nymphs harm period control index

According to the control cost and control effect, according to the economic level and economic threshold allows the hazards, analysis to determine the two instar nymph period of damage control index.

\section{RESULTS AND ANALYSIS}

\section{A. Influence the occurrence of Chinese pine shoot scale increase of pine $\mathrm{DBH}$}

Significance test is carried out to survey 4 years 2004-2008 years of Chinese pine DBH growth amount of results, developed the effects of different population density of pine shoot scale to pine $\mathrm{DBH}$ growth volume table (see Table 1),it is seen from table 2 can, with the increase in population density, diameter at breast height growth of Pinus tabulaeformis were decreased trend, shows that the Chinese pine shoot scale damage effects of DBH growth of Pinus tabulaeformis. When the population density of essthan 300-350 per hundred beam conifer, Pinus tabulaeformis DBH growth by the pine shoot pest is not significant; when the insect density reached 300-350 head/100 beam conifer, Pinus tabulaeformis DBH growth between the quantity and the control showed significant difference.

TABLE.II. EFFECT OF DIFFERENT DENSITY OF INSECT PEST OF CHINESE PINE SHOOT OF CHINESE PINE DBH GROWTH AMOUNT

\begin{tabular}{|c|c|c|c|c|c|c|}
\hline \multirow[b]{2}{*}{$\begin{array}{l}\text { Population } \\
\text { density(hea } \\
\text { d/100 beam } \\
\text { needle) }\end{array}$} & \multicolumn{5}{|c|}{ DBH growth quantity $(\mathrm{cm})$} & \multirow[b]{2}{*}{$\begin{array}{l}\text { Annu } \\
\text { al } \\
\text { and }\end{array}$} \\
\hline & $\begin{array}{c}2004-2 \\
005\end{array}$ & $\begin{array}{c}2005-2 \\
006\end{array}$ & $\begin{array}{c}2006-2 \\
007\end{array}$ & $\begin{array}{c}2007-2 \\
008\end{array}$ & $\begin{array}{c}\text { The } \\
\text { avera } \\
\text { ge } \\
\text { annu } \\
\text { al }\end{array}$ & \\
\hline 350above & 0.078 & 0.049 & 0.143 & 0.079 & $\begin{array}{c}0.08 \\
7\end{array}$ & $\begin{array}{c}0.349 \\
\mathrm{~b}\end{array}$ \\
\hline $300-350$ & 0.123 & 0.280 & 0.431 & 0.327 & $\begin{array}{c}0.29 \\
0\end{array}$ & $\begin{array}{c}1.161 \\
\mathrm{ab}\end{array}$ \\
\hline $250-300$ & 0.215 & 0.455 & 0.599 & 0.575 & $\begin{array}{c}0.46 \\
1\end{array}$ & $\begin{array}{c}1.844 \\
\mathrm{a}\end{array}$ \\
\hline $200-250$ & 0.337 & 0.602 & 0.639 & 0.626 & $\begin{array}{c}0.55 \\
1\end{array}$ & $\begin{array}{c}2.204 \\
\mathrm{a}\end{array}$ \\
\hline $150-200$ & 0.445 & 0.630 & 0.676 & 0.662 & $\begin{array}{c}0.60 \\
3\end{array}$ & $\begin{array}{c}2.413 \\
\mathrm{a}\end{array}$ \\
\hline
\end{tabular}

$\begin{array}{ccccccc}100-150 & 0.451 & 0.633 & 0.715 & 0.630 & \begin{array}{c}0.60 \\ 7\end{array} & \begin{array}{c}2.429 \\ \mathrm{a}\end{array} \\ 50-100 & 0.322 & 0.665 & 0.743 & 0.638 & \begin{array}{c}0.59 \\ 2\end{array} & \begin{array}{c}2.368 \\ \mathrm{a}\end{array} \\ & & & & & 0.61 & \begin{array}{c}2.441 \\ 0\end{array} \\ \text { CK } & 0.321 & 0.687 & 0.743 & 0.690 & \begin{array}{c}0 \\ \mathrm{a}\end{array} \\ & & & & & 0.62 & \begin{array}{c}2.478 \\ \mathrm{a}\end{array} \\ \text { Total } & 0.322 & 0.674 & 0.743 & 0.739 & 0 & 17.68 \\ 7\end{array}$

B. Influence the occurrence of Chinese pine shoot scale increase of Pinus tabulaeformisvolume

The occurrence of the Chinese pine shoot scale effect on the growth of Pinus tabulaeformis volume weight is shown in Table 3, significant test shows that, when the population density reached $250-300$ head/100 beam coniferous, volume growth was significantly different between the quantity and the control.

TABLE.III. THE EFFECT OF OCCURRENCE OF PINE SHOOT SCALE INCREASE OF PINUS TABULAEFORMISVOLUME

\begin{tabular}{|c|c|c|c|c|c|c|}
\hline \multirow[b]{2}{*}{$\begin{array}{c}\text { Population } \\
\text { density(he } \\
\text { ad/100 } \\
\text { beam } \\
\text { needle) }\end{array}$} & \multicolumn{6}{|c|}{ Volume increment $(\mathrm{cm})$} \\
\hline & $\begin{array}{l}2004-- \\
2005\end{array}$ & $\begin{array}{c}2005-- \\
2006\end{array}$ & $\begin{array}{c}2006-2 \\
007\end{array}$ & $\begin{array}{c}2007-2 \\
008\end{array}$ & $\begin{array}{c}\text { The } \\
\text { aver } \\
\text { age } \\
\text { annu } \\
\text { al } \\
\end{array}$ & $\begin{array}{l}\text { Annu } \\
\text { al and }\end{array}$ \\
\hline 350above & 0.0008 & 0.0005 & 0.0015 & 0.0009 & $\begin{array}{c}0.00 \\
09\end{array}$ & $\begin{array}{c}0.003 \\
8 b\end{array}$ \\
\hline $300-350$ & 0.0013 & 0.0031 & 0.0050 & 0.0041 & $\begin{array}{c}0.00 \\
34\end{array}$ & $\begin{array}{c}0.013 \\
4 \mathrm{ab}\end{array}$ \\
\hline $250-300$ & 0.0023 & 0.0052 & 0.0075 & 0.0079 & $\begin{array}{c}0.00 \\
57\end{array}$ & $\begin{array}{c}0.023 \\
0 \mathrm{ab}\end{array}$ \\
\hline $200-250$ & 0.0038 & 0.0074 & 0.0087 & 0.0093 & $\begin{array}{c}0.00 \\
73\end{array}$ & $\begin{array}{c}0.029 \\
2 \mathrm{a}\end{array}$ \\
\hline $150-200$ & 0.0047 & 0.0072 & 0.0087 & 0.0094 & $\begin{array}{c}0.00 \\
75\end{array}$ & $\begin{array}{c}0.030 \\
0 \mathrm{a}\end{array}$ \\
\hline $100-150$ & 0.0048 & 0.0074 & 0.0094 & 0.0092 & $\begin{array}{c}0.00 \\
77\end{array}$ & $\begin{array}{c}0.030 \\
8 \mathrm{a}\end{array}$ \\
\hline $50-100$ & 0.0036 & 0.0081 & 0.0100 & 0.0098 & $\begin{array}{c}0.00 \\
78\end{array}$ & $\begin{array}{c}0.031 \\
4 \mathrm{a}\end{array}$ \\
\hline $0-50$ & 0.0035 & 0.0081 & 0.0098 & 0.0102 & $\begin{array}{c}0.00 \\
79\end{array}$ & $\begin{array}{c}0.031 \\
5 \mathrm{a}\end{array}$ \\
\hline CK & 0.0034 & 0.0078 & 0.0096 & 0.0107 & $\begin{array}{c}0.00 \\
79\end{array}$ & $\begin{array}{c}0.031 \\
6 \mathrm{a}\end{array}$ \\
\hline Total & 0.0282 & 0.0548 & 0.0702 & 0.0714 & & $\begin{array}{c}0.224 \\
7\end{array}$ \\
\hline
\end{tabular}

\section{Determination of Chinese pine shoot pest control index}

The occurrence of the Chinese pine shoot scale has affected the growth and volume of Pinus tabulaeformis growth. As for Chinese pine shoot scale effective prevention and treatment, and obtained better economic benefit, formulate scientific and reasonable control index is the key problem to be solved. 
1) Establishes the regression equation:

Table 3 the insect mouth density interval intermediary values, then the intermediate value and, annual volume average growth of the regression analysis, a relationship between the two (parabola, two regression) are as follows:

$$
\begin{gathered}
y=0.0075135+0.000016354 x-0.000000088679 x^{2} \\
r=-0.8561
\end{gathered}
$$

2) Determine the control index:

According to the regression equation, the insect mouth density $(Z)$ of Pinus tabulaeformis growth and volume(V)relationship model:

\section{$\mathrm{Vz}=0.0075135+0.000016354 Z-0.000000088679 Z^{\wedge} 2:$}

When $\mathrm{Z}=0, \mathrm{~V} 0=0.0075135$

Make Vz'for the loss amount per hectare pine volume, is a function of population density of $\mathrm{Z}$, then:

$$
\mathrm{Vz}^{\prime}=\mathrm{V} 0-\mathrm{Vz}=-0.000016354 \mathrm{Z}+0.000000088679 \mathrm{Z}^{\wedge} 2
$$

According to $\mathrm{Ci}=\mathrm{Vz}^{\prime} * \mathrm{Si}^{*} \mathrm{Ni} * \mathrm{Mi}$, where $\mathrm{Ci}$ is the cost of control( $\$ / \mathrm{hm} 2)$, Si value $(\$ / \mathrm{m} 3)$ of Pinus tabulaeformis,

$\mathrm{Ni}$ as the control effect, Mi number per hectare pine tree, there are:

$$
\begin{aligned}
& \mathrm{Ci}=\mathrm{Vz} * \mathrm{Si}^{*} \mathrm{Ni} * \mathrm{Mi} \\
& =(\mathrm{V} 0-\mathrm{Vz}) * \mathrm{Si}^{*} \mathrm{Ni} * \mathrm{Mi} \\
& =(-0.000016354 \mathrm{Z}+0.000000088679 \mathrm{Z} 2) * \mathrm{Si}^{*} \mathrm{Ni} * \mathrm{Mi}
\end{aligned}
$$

After that a market survey in recent years, the average value of Chinese pine(Si)of about 500 yuan $/ \mathrm{m} 3$,stem number per hectare(Mi)about 1000 strains, the control effect(Ni)was $80 \%$, the cost of control(Ci)is 300 yuan $/ \mathrm{hm} 2$, there are:

$$
300=(-0.000016354 \mathrm{Z}+0.000000088679 \mathrm{Z} 2) * 500 * 0.8 * 1000
$$

That is: $0.037689 \mathrm{Z2}-6.95045 \mathrm{Z}-300=0$

Solutions of Chinese pine shoot pest control index of Pinus tabulaeformis:

\section{$\mathrm{Z}=220.5(\mathrm{head} / 100$ beam coniferous $)$}

According to the occurrence and development regularity of pine shoot scale, life habit and the insect mouth density influence the correlation between diameter at breast Height and of pinus tabulaeformis growth, to determine the two instar theory control index was 220.5 per hundred beam coniferous, has guiding significance for production practice

\section{CONCLUSION AND DISCUSSION}

Increase the volume of Pinus tabulaeformis growth and DBH are subject to damage of Chinese pine shoot scale. When the population density of less than 300-350 per hundered beam coniferous, no loss of DBH growth, when the insect density more than $300-350$ per hundred beam coniferous, Chinese pine shoot scale significantly affect pine growth; effect on volume growth, when zhe population density of less than 250-300 per hundred beam coniferous, volume accumulation is not affected, when the insect density reached 250-300 head/100 beam needles at the pine shoot scale significantly influence the accumulation of Pinus tabulaeformis volume.

By calculation, determine the pine shoot scale main harmful pest period(2 instar) theory control index was 220.5 per hundred beam coniferous. But the control index is not fixed, will because of the difference of insect and harm of season, the level of management and control measures, control effect, control cost, natural enemies and climate factors and soil condition and different. Limited by the experimental condition, may also exist certain errors in the formulation of control index. Therefore, all localities should be adjusted according to the actual situation in the implementation.

\section{REFERENCES}

[1] Compilation Committee of Lushi county.Lushi county annals[M].Henan: Zhongzhou Classics Publishing House,1998

[2] Guang Zengyun ed.Xing Tieniu.Henan Province,the main tree species of tree volumeand shape of high surface[M].Zhengzhou: the Yellow River Water Conservancy Press,1998-07

[3] Gao Yang Guo Jianxun, high Jiusi,pine shoot scale. The biological characteristics andecological habits of overview of [J].Shaanxi Agricultural Sciences,2010,56(6):54-56.

[4] Zhang Gaixiang. Western Henan Chinese pine and environmental factors of occurrenceand shoot scale relations between[J].and plant quarantine,2009(2):11-14.

[5] Ning Sun, Zhang Kang.The pine mealybug hazards and control[J].Shaanxi forestry,2008,(4):40

[6] in the crown by,Peng Xinglong,Zhang Gaixiang,etc.in western Henan Matsucoccus sinensis biological and ecological characteristics of a preliminary study of[J].China forest pests,2006,25(2):12-14.

[7] Zhang Zhenyin.Matsucoccus sinensis biological characteristics and control technology of [J].China forest pests,2002,21(3):28-29.

[8] Li Xiangwei,Yin Fujie,Wang Bing,et al.Matsucoccus sinensis in canopy spatialpopulation distribution characteristics[J].Journal of Henan Agricultural University,1997,31(1):67-69.

[9] Li Jiayuan,Chen Wenrong.The pine shoot pest biological characteristics and prevention research[J].Journal of Fujian Forestry University,1991(1):84-91.

[10] Li Xiangwei, Yang Huizhao,et al.Effect of high Shuifan,harm of Matsucoccus sinensisgrowth of Pinus tabulaeformis[J].Journal of Henan Vocation Technical Teachers College,1991,19(3):36-41.

[11] Zhang Gu could.T he insect population life table of key factor analysis method in the[J].graduate of Zhongshan University Journal:Natural Science Edition,1994,15(1):72-79

[12] Ji Xing Lin. Pine needle scale harm and comprehensive prevention and control technology of[J].modern rural science and technology,2011(8):30 